det spørgsmål, hvad der er vundet ved at rehabilitere nyplatonikernes bastante, hierarkiserede metafysik.

Jakob Leth Fink

\section{Russells frontalangreb}

Oversattelse og indledning ved Flemming Chr. Nielsen. Forlaget Bindslev 2007, 124 s., $148 \mathrm{kr}$.

Bertrand Russell var blandt det tyvende århundredes mest produktive og farverige filosoffer. Han havde enestående flair for logik såvel som for polemik. I denne essaysamling er det sidstnæunte talent, der kommer til sin ret, og det ikke sjældent på bekostning af logikken. Russells tekster udfolder sig som et frontalangreb på religionen, særligt kristendommen. I Russells argumenter er der - undskyld udtrykket - intet nyt under solen. Mennesker tror på Gud, fordi de higer efter sikkerhed. Religion udspringer af frygt for det ukendte og for døden, og er grundlæggende et produkt af menneskelig svaghed og irrationalitet. Med Russells metafor er religionen dragen, der vogter porten til den gyldne tidsalder, der venter menneskeheden, såfremt den tør gribe verden rationelt an. Dragen må og skal slås ned. Det er et spørgsmål om fornuft eller døden.

Hvis man en kort stund - og den behøver kun være kort, for det er en lille bog - ser bort fra, at Russells diagnostik hverken historisk, sociolo- gisk eller filosofisk er holdbar, så er det en stor fornøjelse at læse den veloplagte bog. Med sin blanding af ironi og indignation er Russell et langt mere interessant bekendtskab end de tågehorn, der er i dag siger omtrent det samme, bare mere blodfattigt.

Flemming Chr. Nielsen står bag et fint valg og en god oversættelse af Russells originale essaysamling fra 1957, der i øvrigt udkom på dansk $\mathrm{i}$ sin fulde længde i $1966.148 \mathrm{kr}$. for 124 meget små sider er dog i overkanten.

Casper Andersen 